\title{
Analytical Study of Information Need and Seeking Behaviour of Agricultural Researchers in Nigeria
}

\author{
Janet Oluwakemi Oyeniyi ${ }^{1}$
}

\begin{abstract}
${ }^{1}$ Deputy Director (Library Services), National Centre for Agricultural Mechanisation, P. M. B 1525, Ilorin, Kwara State Nigeria
\end{abstract}

\begin{abstract}
Information is an essential and integral part of all human endeavours. Research endeavour is primarily built on seeking information with which researchers arrive at findings and their conclusions. The output of any research is an outcome of the quality and quantity of information that researchers could obtain. In spite of the Nigerian government funding of agricultural research, the output from the effort has not been significant. Therefore the study investigated the information seeking behaviour of agricultural researchers in Nigeria. The objectives of the study are to (i) identify information providers used by agricultural researchers in seeking information (ii) investigate how often researchers access information sources (iii) ascertain the researchers opinions on purposes of visiting the library (iv) investigate most preferred source for up-to-date information by agricultural researchers and (v) determine the most preferred collection for accessing information.Questionnaire was used to collect information from a carefully selected 450 researchers from agricultural research institution that are under (ARCN). The finding of the study revealed that information providers used mainly by agricultural researchers are internet, colleague's collections and the library while printed journals are frequently accessed information source. Majority visit the library just to access reference materials while the most preferred sources for up-to-date information is attending conferences, lectures and seminars. Therefore the study concluded that when seeking information, majority of agricultural researchers in Nigeria prefers internet to library collection which in most cases are obsolete, although the two are still the major information providers in many of the research institution.
\end{abstract}

\begin{abstract}
Introduction
Information could be described as facts provided or learned about something or someone. It can also be described or seen as valuable because it can affect behaviour, a decision or an outcome. According to Rouse (2000) information is a stimulus that has meaning in some context for its receiver. When information is stored in a computer, it is generally referred to as data. After processing (such as formatting and printing), output data can again be perceived as information. Anwar (2007), defined information as recorded experience that is used in decision making.
\end{abstract}

Mabawonku (2005), highlighted some ways in which students sought for information, which include: through their colleagues, the internet, library, family members, recognized institutions, agencies and private organization. Kakai et.al. (2004), also described information source as an individual's way and manner of gathering and sourcing for information for personal use, knowledge updating and development.

Andrzej (2007), sees information as an abstract entity. He opined that information has no separate existence on its own, because no difference can exist when there are real states of affairs between which the difference holds and which constitute its code. The same information can be encoded in various ways e.g. a piece of music can be encoded on a magnetic tape, on a piece of paper, on a compact disc etc. Different codes encode the same information if the involved collections are isomorphic.
Information, according to Annan (2003), is the key to just about everything. He stated that good and abundant information helps the society to understand a situation, manage expectation between individuals, plan and prioritize. He also added that information helps to investigate, understand potential consequences, and as well help to have better interactions with people. He further noted that information is a way for human capacity to be expanded, built up, nourished and liberated by giving people access to tools and technologies, with the education and training to use them effectively. Information serves as a unique opportunity to connect and assist those living in poor and most isolated regions of the world. Annan (2003) noted that informatization of society is a major hurdle that most nations especially the developing countries are encountering. He further stated that information society or information age is a phenomenon that began after 1950, which brings challenges as we seek to integrate and expand the universe of print and multi- media sources.

Meanwhile human activities on information and the process of finding such information led to another concept termed information seeking behaviour. This concept according to Wilson (1999) emerged as a consequence of a need perceived by information users making demands upon formal or informal information sources or services. The concept Wilson (1999) opined evolved to relate the activities a person may engaged in when identifying their own needs for information, searching for such information in anyway, and using or transferring of that information. 


\section{Literature Review}

Information seeking was defined by Bates (2010) as the process or activity of attempting to obtain information in both human and technological contexts. Information seeking is related to but different from information retrieval (IR). Traditionally, IR tools have been designed for IR professionals to enable them effectively and efficiently retrieve information from a source. It is assumed that information exists in the source and that a well-formed query will help to retrieve it. It has been argued that laypersons' information seeking in the internet is very different from information retrieval as performed within the IR discourses.

Information seeking may be understood as a more human oriented and open-ended process than information retrieval. In information seeking, one does not know whether there exists an answer to one's query, so the process of seeking may provide the learning required to satisfy one's information needs. Meanwhile, according to Singh and Satijah (2007) information seeking behaviour (ISB) is a process that requires adaptive and reflective control over inference and reference actions of the information seeker. ISB, he further stated, resulted from the recognition of some needs perceived by the user who as a consequences make demand upon a former system such as library and information centre, or some other person in order to satisfy the perceived information need.

Kakai et.al. (2004) defined information- seeking behaviour as an individual's ways and manner of gathering and sourcing for information for personal use, knowledge updating and development. However, Majid and Kassim (2000) had earlier described information seeking behaviour as a broad term, which involves a set of actions that an individual takes to express information needs, seeking information, evaluate and select information and finally uses this information to satisfy his/her information needs.

A review of literature on information seeking behaviour shows that information seeking has generally been accepted as dynamic and non-linear, Kuhlthau (2005). People experience the information search process as interplay of thoughts, feelings and actions. Given the background to the term "information behaviour" Bates (2010), recalled that studies on it were first called "users studies" and later "information seeking and gathering" or "study of information needs and uses". Gradually the term "information seeking research" was used to include all kinds of research on people's interaction with information. He stated further that in recent years the term "information behaviour" came to be widely used to replace information seeking. The term "information seeking behaviour" is now commonly being used to know how people interact with information.

According to Case (2007), information seeking has been found to be linked to a variety of interpersonal communication behaviours beyond question asking. Meanwhile Robinson (2010) study revealed that when seeking information at work, people rely on both other people and information repositories like documents and databases and spend similar amounts of time consulting each .However, this distribution of time among the constituent information seeking stages differ depending on the source. When consulting other people, people spend less time locating the information source and information within that source, similar time understanding the information, and more time problem solving and decision making, than when consulting information repositories. Furthermore, he found that people spend substantially more time receiving information passively i.e. (information that they have not requested) than actively (information they have requested) and this pattern is also reflected when they provide others with information.

Spencer (2006), identify there are four modes of seeking information which include firstly, "knownitem" where the user knows what they want, knows what words to use to describe it, and may have a fairly good understanding of where to start. In addition, the user maybe happy with the first answer they find (though not always) and the task may not change significantly during the process of finding the answer. The second one is the "exploratory task", people have some idea of what they need to know. However, they may or may not know how to articulate it and if they can, may not yet know the right words to use, they may not know where to start to look. They will usually recognize when they have found the right answer, but may not know whether they have found enough information.

The third mode is "don't know" attitude where people often don't know exactly what they need to know. They may think they need one thing but need another, or they may be looking at a website without a specific goal in mind. The last one is that of "refinding" where users are looking for things they have already seen. They may remember exactly where it is, remember what site it was on or have little idea about where it was.

According to Kuhlthau (2005) information workers consider information seeking as a necessary, but preliminary activity, to the more significant endeavour of using information for constructing new knowledge to accomplish the tasks and goal that encompass their work. Information seeking is one task in a series of activities performed to fulfil a greater need. He further stated that information takes many forms. It might be news, announcement, gossips, opinion, advisories or raw data. The information at hand might be good or bad or even intentionally misleading, but one have to deal with, one way or the other but always seek information in addition to what is provided so that one can:

- $\quad$ verify claim

- $\quad$ stimulate new ideas

- make use of different perspective

- $\quad$ provide more options to choose from, and lastly

- have a re-bust discussion with yourself and others. (Kuhlthau:2005)

Information seeking behaviour, according to Bates (2010), is the currently preferred term used to describe the many ways in which human beings interact with information, in particular, the ways in which people seek and utilize information. Interest in this area, according to him, developed out of several 
streams, because librarians wanted to understand library users better and government agencies wanted to understand how scientists and engineers use technical information. In order to promote more rapid update of new research results, social scientists generally were interested in the use of information in a variety of senses. He concluded that in more recent years, social studies of information technology and social informatics have contributed to this area as well. Yousefi and Yousefi (2007), observed that the number of information resources has increased considerably; and the emergence of new information environment, sources and channels, especially the World Wide Web (www) regardless of the advantages, has brought new challenges and problems. They stressed that retrieval of information in response to users' real needs have become even more complex; on the other hand, assessing the validity and reliability of retrieved information is a considerable problem.

Spicker (2007) opined there can be no research without information. He also ascertained that information is needed from beginning to the end of any reliable research. In Nigeria, like most other developing countries, economic and social development are been shifted to agriculture. Therefore in order to achieve sustained progress in agricultural sector Shaib et.al (2003), observed that three basic ingredients are required. They include appropriate technology, supporting policies, strong institutional capacity and good information source. In view of this, various countries of the world established universities and agricultural research institutions in order to solve agricultural problems. This is also the case in Nigeria where the improvement of available agricultural technologies and generation of new ones are hinged on research activities of scholars in different agricultural institutions. Prominent among them are research staff members in various Nigerian agricultural research institutes spread across the entire geo-political zones of the country. This was supported by Ezeala and Yusuff (2011), that most developing countries like Nigeria, it is an important sector of the economy. Many countries, including Nigeria have realized the value of agriculture and are making attempt to sustain it by pragmatic agricultural policies. One of such policies in Nigeria is the establishment of specialized institutions otherwise known as research institutes, to carry out research in agriculture for socio-economic development of the country. These specialized institutions which enhance agricultural development largely rely on libraries and their information services.

In Nigeria research institutions as observed by Ankpa (2000) research is lagging behind in their productivities for sustainable agricultural development which is as a result of their research activities. It is noted that there are no scientific investigation that can take place without the knowledge acquired in the past through information. The way people seek information on their research activities is very important. Could it be that the agricultural researchers are not getting enough information or that their information seeking behaviour are Faulty? Since it has been established that man needs information for day to day activities, it is therefore imperative to study information seeking behaviour. These will help the information provider to access and strategies for better service.

\section{Objectives of the Study}

The broad objective of the study therefore is to identify the information seeking behaviour of agricultural researchers in Nigeria; while the specific objectives are:

1. identify information providers used by researchers in seeking information

2. investigate how often researchers access information sources

3. ascertain the researchers opinions on purposes of visiting the library

4. investigate most preferred source for up-to-date information by agricultural researchers

5. determine the most preferred collection for accessing information

\section{Findings}

The population of this study consisted of agricultural researchers in all agricultural research institutions that are under the Agricultural Research Council of Nigeria (ARCN). These institutions are fifteen in number located all over the six geo-political zones of Nigeria and are being supervised by the ARCN but have different mandates. Each of these institutions has a mandate to carry out different researches peculiar to their zone, in a bid to improving agricultural standards in the country.

All researchers in the fifteen (15) agricultural research institutions in Nigeria serve as the population for this study.

Table 3.1: Research Institutions Showing Numbers of Research Staff.

\begin{tabular}{|l|l|l|l|}
\hline S/No & Research Institution & Geo-political Zone & $\begin{array}{c}\text { Research-Staff } \\
\text { Strength }\end{array}$ \\
\hline 1. & $\begin{array}{l}\text { Cocoa Research Institute of Nigeria (CRIN) } \\
\text { Ibadan, Oyo State }\end{array}$ & South-West & 65 \\
\hline 2. & $\begin{array}{l}\text { Institute of Agricultural Research and Training } \\
\text { IAR and T) Ibadan, Oyo State. }\end{array}$ & South-West & 58 \\
\hline 3. & $\begin{array}{l}\text { National Institute for Horticulture (NIHORT) } \\
\text { Ibadan. Oyo State }\end{array}$ & South-West & 67 \\
\hline 4. & $\begin{array}{l}\text { Nigerian Institute for Oceanography and Marine } \\
\text { Research (NIOMR) Lagos, Lagos State }\end{array}$ & South-West & 62 \\
\hline 5. & $\begin{array}{l}\text { Nigerian Stored Products } \\
\text { Research Institute(NSPRI) Ilorin, Kwara State }\end{array}$ & North-Central & 71 \\
\hline 6. & $\begin{array}{l}\text { National Cereal Research Institute (NCRI) } \\
\text { Baddegi, Niger State. }\end{array}$ & North Central & 63 \\
\hline
\end{tabular}




\begin{tabular}{|l|l|l|l||}
\hline 7. & $\begin{array}{l}\text { National Veterinary Research Institute of Nigeria } \\
\text { (NVRI) Vom, Plateau State }\end{array}$ & North - Central & 65 \\
\hline 8. & $\begin{array}{l}\text { National Institute for Freshwater } \\
\text { Research (NIFFR) New Bussa, Niger State }\end{array}$ & North-Central & 67 \\
\hline 9. & $\begin{array}{l}\text { National Animal Production Research Institute } \\
\text { (NAPRI) Zaria, Kaduna State }\end{array}$ & North - West & 52 \\
\hline 10. & $\begin{array}{l}\text { National Agricultural Extension and Research } \\
\text { Liaison Services (NAERLS) Ahmadu Bello } \\
\text { University Zaria, Kaduna State }\end{array}$ & North - West \\
\hline 11. & $\begin{array}{l}\text { Institute of Agriculture Research (IAR)Ahmadu } \\
\text { Bello University, Zaria, Kaduna State }\end{array}$ & North - West & 53 \\
\hline 12. & $\begin{array}{l}\text { Rubber Research Institute of Nigeria (RRIN) Benin, } \\
\text { Edo State. }\end{array}$ & South - South & 61 \\
\hline 13. & $\begin{array}{l}\text { National Institute for Oil Palm } \\
\text { Research (NIFOR) Benin, Edo State }\end{array}$ & South - South \\
\hline 14. & $\begin{array}{l}\text { Lake Chad Research Institute } \\
\text { (LCRI) Maiduguri, Borno State }\end{array}$ & 67 \\
\hline 15. & $\begin{array}{l}\text { National Root Crops Research Institute (NRCRI) } \\
\text { Umudike, Abia State. }\end{array}$ & South - East & 61 \\
\hline & & TOTAL & 920 \\
\hline
\end{tabular}

Table 1: Information providers used by agricultural researchers in seeking information

\begin{tabular}{|l|l|l|l|}
\hline & Frequently & Occasionally & Never \\
\hline Library & $292(64.0)$ & $160(35.1)$ & $4(0.9)$ \\
\hline Internet & $439(96.2)$ & $15(3.3)$ & $2(0.4)$ \\
\hline Archives & $121(38.0)$ & $162(50.8)$ & $36(11.3)$ \\
\hline Social media & $234(67.4)$ & $91(26.2)$ & $22(6.3)$ \\
\hline $\begin{array}{l}\text { Direct supervisors/ } \\
\text { Head of sections }\end{array}$ & $260(68.0)$ & $110(28.8)$ & $12(3.1)$ \\
\hline Colleagues & $308(75.5)$ & $94(23.0)$ & $6(1.5)$ \\
\hline Other & $61(48.8)$ & $48(38.4)$ & $16(12.8)$ \\
\hline
\end{tabular}

Table 1 provides the summary of respondents opinion on which of the information providers they often use for information regarding their research. From the table $292(64.0 \%)$ frequently used the library, 160 $(35.1 \%)$ occasionally used the library while only 4 $(0.9 \%)$ never used the library. Internet usage has majority number of $439(96.2 \%)$ of the respondents that frequently used internet, $15(3.3 \%)$ that used it occasionally while only $2(0.4 \%)$ that never used it. Archive has an information provider has 121 (38.0\%) frequent usage, $162(50.8 \%)$ occasionally and 36 $(11.3 \%)$ that never used it. Social media is another information provider which has 234(67.4\%) respondents that frequently used it, 91(26.2\%) occasionally and $22(6.3 \%)$ that never used it. Similarly on the respondents opinion on direct supervisor or head of section as an information provider 260 ( $68.0 \%$ ) respondents frequently used it, $110(28.8 \%)$ used it occasionally while $12(3.1 \%)$ never used it. Another information provider identified is colleagues which has the majority number of 308 $(75.5 \%)$ respondents that frequently used it, 94 $(23.0 \%)$ occasionally and only $6(1.5 \%)$ never used it.

Table 2: Respondents' opinions on how often agricultural researchers access the following information sources

\begin{tabular}{|l|l|l|l|}
\hline & frequently & Occasionally & Never \\
\hline Books & $393(86.5)$ & $61(13.4)$ & - \\
\hline Print Journals & $401(88.3)$ & $49(10.8)$ & $4(0.9)$ \\
\hline Internet sources & $436(94.0)$ & $23(5.0)$ & $5(1.1)$ \\
\hline $\begin{array}{l}\text { Library electronic materials and } \\
\text { Database }\end{array}$ & $289(65.7)$ & $134(30.5)$ & $17(3.9)$ \\
\hline $\begin{array}{l}\text { Thesis/Dissertation/ Conference } \\
\text { proceedings }\end{array}$ & $295(66.4)$ & $134(30.2)$ & $15(3.4)$ \\
\hline $\begin{array}{l}\text { Indexes/Abstracts/ } \\
\text { Bibliographies }\end{array}$ & $223(51.5)$ & $180(41.6)$ & $30(6.9)$ \\
\hline
\end{tabular}

Table 2 which represents the opinion of respondents on how often they accessed some sources of information, showed that internet source has majority $436(94.0 \%)$ respondents that accessed it frequently, $23(5.0 \%)$ occasionally, and only $5(1.1 \%)$ never accessed the internet. This was closely followed by print journals that has $401(88.3 \%)$ respondents who accessed it frequently, $49(10.8 \%)$ occasionally and insignificant number of $4(0.9 \%)$ that never accessed it. Books represent another source of information with 393(86.5\%) respondents that accessed it frequently, 61(13.4\%) occasionally and no respondent that never accessed book. Thesis/ Dissertation/Conference Proceedings had 295 $(66.4 \%)$ of the respondents that accessed it frequently, 134(30.2\%) occasionally, while $15(3.4 \%)$ never accessed it. Library electronic and data bases has $295(66.4 \%)$ respondents that uses it frequently, 
$134(30.5 \%)$ accessed it occasionally and only 17(3.9) never used it. Another information source is thesis/ dissertation and conference proceedings which has $295(66.4 \%)$ respondents that frequently accessed it, $134(30.2 \%)$ occasionally and only $15(3.4 \%)$ that never accessed it. Last on the list is Indexes/ Abstract/ Bibliography with 223 (51.5\%) respondents frequently accessed it, $180(41.6 \%)$ occasionally accessed it while $30(6.9 \%)$ never assessed this source of information. From the table it can be deduced that Internet source has the highest numbers of respondents that frequently accesses it followed by printed journal, books and electronic data base all available in the library. This attests to the fact that both the internet and the library are good sources of information provider for agricultural researchers in Nigeria. This is expected since it has been revealed that the highest information provider used by researchers is the internet and then library, definitely respondents' opinion on how often they accessed these information sources will not differ.

Table 3: Respondents' opinions on purposes of visiting the library

\begin{tabular}{|l|l|l|l|}
\hline Purpose of visiting the library & frequently & Occasionally & Never \\
\hline To borrow books & $186(43.6)$ & $204(47.9)$ & $36(8.5)$ \\
\hline To access periodicals & $208(51.4)$ & $161(39.9)$ & $35(8.7)$ \\
\hline To access reference materials & $263(65.0)$ & $121(29.9)$ & $21(5.2)$ \\
\hline $\begin{array}{l}\text { To read newspapers and } \\
\text { magazines }\end{array}$ & $202(50.3)$ & $151(37.6)$ & $49(12.2)$ \\
\hline For general reading & $210(52.6)$ & $166(41.6)$ & $23(5.8)$ \\
\hline To know latest arrivals & $181(49.8)$ & $147(40.5)$ & $35(9.6)$ \\
\hline Others & $58(41.4)$ & $57(40.7)$ & $25(17.9)$ \\
\hline
\end{tabular}

Table 3 sought to investigate further the respondents' opinions on the purpose of visiting the library. In other to borrow books, $186(43.6 \%)$ respondents visited frequently, 204(49.9) occasionally and 36 $(8.5 \%)$ never. In other to access periodicals, 208 $(51.1 \%)$ respondents does that frequently, 161 ((39.9) occasionally and $35(8.7 \%)$ never. For the purpose of accessing reference materials $263(65 \%)$ frequently, $121(29.9 \%)$ occasionally while $21(5.2 \%)$ never. For the purpose of reading newspapers and magazines $202(50.3 \%)$ does that frequently, 151(37.6\%) occasionally and $49(12.2 \%)$ never. For general reading $210(52.6 \%)$ respondents does frequently, $147(40.5 \%)$ occasionally and $35(9.6 \%)$ never. In other to know the latest arrival $181 \quad(49.8 \%)$ respondent frequently, $147(40.5 \%)$ occasionally while only $35(9.6 \%)$ visit the library for that purpose.

Table 4: Respondents' most preferred source for up-to-date information

\begin{tabular}{|l|l|l|l|}
\hline Source for up- to-date information & Frequently & Occasionally & Never \\
\hline Conversation with colleagues and experts & $323(78.0)$ & $88(21.3)$ & $3(0.7)$ \\
\hline Attending conference, lectures and seminar & $336(76.5)$ & $100(22.8)$ & $3(0.7)$ \\
\hline Conference proceedings & $330(77.8)$ & $86(20.3)$ & $8(1.9)$ \\
\hline Technical research expert & $309(76.3)$ & $91(22.5)$ & $5(1.2)$ \\
\hline Reference found while reading online literature & $316(76.5)$ & $86(20.8)$ & $11(2.7)$ \\
\hline Books, monograph etc. & $307(74.0)$ & $92(22.2)$ & $16(3.9)$ \\
\hline Abstract, Index, Bibliography and periodicals & $237(60.5)$ & $139(35.5)$ & $16(4.1)$ \\
\hline Year book / annual review. & $218(56.2)$ & $151(38.9)$ & $19(4.9)$ \\
\hline Library catalogues, Library acquisitions lists & $176(45.5)$ & $180(46.5)$ & $31(8.0)$ \\
\hline Pre-prints from authors & $143(40.9)$ & $155(44.3)$ & $52(14.9)$ \\
\hline
\end{tabular}

Table 4 represents the most preferred source for upto-date information from the respondents. The table revealed that $323(78.0 \%)$ frequently preferred conversation with colleagues and experts in their various field, $88(21.3 \%)$ occasionally preferred it while only $3(0.7 \%)$ never preferred it. Attending conference, lecture and seminar has $336(76.5 \%)$ respondents that frequently preferred it for up-to-date information, $100(22.8 \%)$ occasionally preferred it while only $3(0.7 \%)$ does. Similarly, conference proceedings has $330(77.8 \%)$ respondents that frequently used it, $86(20.3 \%)$ occasionally used it and only $8(1.9 \%)$ that never used it. Further still, the opinion of the respondents on using technical research experts revealed that $309(76.3 \%)$ frequently preferred it for up-to-date information, 91(22.5\%) occasionally while $5(1.2 \%)$ never preferred it.

Other sources for up-to-date information are reference found while reading online literature which was frequently preferred by $316(76.5 \%)$ of the respondents, $86(20.8)$ occasionally and $11(2.7 \%)$ never preferred the usage. Books and monograph was frequently preferred by $307(74.0 \%)$, occasionally by 92(22.2\%) and 16(3.9\%) never preferred it. Abstract, index, bibliography and periodicals has $237(60.5 \%)$ respondents frequently preferred it, 139(35.5\%) occasionally preferred it while $16(4.1 \%)$ never preferred it. Pre-print from author is another source of information preferred by $143(40.9 \%)$ respondents, $155(44.3 \%)$ occasionally preferred it while $52(14.9 \%)$ respondents never preferred it. 
Table 5: Respondents' most preferred collection for accessing information

\begin{tabular}{|l|l|l|l|}
\hline $\begin{array}{l}\text { Collection for accessing } \\
\text { information }\end{array}$ & Frequently & Occasionally & Never \\
\hline Library collection & $296(68.5)$ & $100(23.1)$ & $36(8.3)$ \\
\hline Personal collection & $323(78.8)$ & $71(17.3)$ & $16(3.9)$ \\
\hline Collection of colleagues & $267(63.3)$ & $128(30.3)$ & $27(6.4)$ \\
\hline Internet collection & $428(93.3)$ & $22(4.8)$ & $6(1.3)$ \\
\hline
\end{tabular}

Table 5 represents the most preferred collection for accessing information. The table revealed that internet collection has the majority of the respondents $428(93.9 \%)$ that frequently preferred it for accessing information, occasionally has $22(4.8 \%)$, while an insignificant number $6(1.3 \%)$ affirmed they never preferred an internet information collection. Personal collection as a source of accessing information has $323(78.8 \%)$ respondent that frequently preferred it, $71(19.3 \%)$ occasionally preferred it while only $16(3.9 \%)$ affirmed never. Another source often used is library collection where $296(68.5 \%)$ respondents frequently preferred it, $100(23.1 \%)$ occasionally preferred it, and 36(8.3\%) never preferred it.

Table 6: Respondents' mode of searching information

\begin{tabular}{|l|l|l|l|}
\hline Mode of searching information & Frequently & Occasionally & To some extent \\
\hline 1.Own/personal effort & $354(78.7)$ & $70(15.6)$ & $26(5.8)$ \\
\hline 2.Computerized information search & $346(75.8)$ & $83(18.2)$ & $27(5.9)$ \\
\hline 3.Supervisor & $143(35.0)$ & $134(32.8)$ & $132(32.2)$ \\
\hline 4.Library staff & $88(22.6)$ & $104(26.7)$ & $198(50.8)$ \\
\hline & & & \\
\hline 6.Colleagues & $151(37.7)$ & $157(39.2)$ & $93(23.2)$ \\
\hline 7.Others & $63(33.7)$ & $40(21.4)$ & $84(44.9)$ \\
\hline
\end{tabular}

Table 6 represents the mode of searching information by the respondents revealed that 354 (78.7) which represents the majority of the respondents frequently preferred personal efforts when searching information, $70(15.6 \%)$ occasionally while $26(5.8)$ preferred it to some extent. Similarly computerizes information search has majority $346(75.8 \%)$ of the respondents that frequently used it, 83(18.2\%) occasionally and only $27(5.9 \%)$ preferred it to some extent. On the usage of supervisor as mode of searching information $143(35.0 \%)$ frequently used it, $134(32.8 \%)$ occasionally and $132(32.2 \%)$ used it to some extent. The table also revealed that $88(22.6 \%)$ respondents frequently used library staff to search for information, 104(26.7\%) occasionally and 198 (50\%) used this mode to some extent. Another important mode identified for searching information is colleagues which showed that 151 (37.7\%) respondents used frequently, 157(39.2\%) used it occasionally while $93(23.2 \%)$ used it to some extent.

Therefore it could be concluded that when seeking information majority of the agricultural researchers in Nigeria prefer the Internet to library; though library and internet are still the two major information providers in many of the research institutions. Apart from internet sourcing, printed journal happens to be the most often accessed information sources in seeking information. When there is need for agricultural researchers to visit the library, it is to access reference materials and to read newspapers and not to borrow books because most of the books are not current. The Agricultural researchers in Nigeria preferred conversation with colleagues and attending conferences, lectures and seminar for up to date information. They also preferred downloaded internet collection and their personal collection to library collections. Similarly they use their own personal effort and computerized information search than getting assistance from Librarian or other library personnel when seeking information.

\section{Recommendation}

Stemming from the findings and conclusion of the study, the following recommendations were made:

1. Access to internet in all agricultural research institutes even after the normal closing hours should be provided since it has been noted that the most preferred source of accessing information is the internet. Efforts should be geared toward upgrading the internet facilities for a broader bandwidth as well as for easy retrieval of information to all researchers. Therefore, agricultural research information centres in Nigeria should provide 24/7 internet facilities for researchers in a bid to enhancing performance and perfect information delivery services.

2. Organization of Seminars and workshops on the use of library and internet searching techniques from time to time for the researchers is very important.

3. Agricultural research institutions in Nigeria should find a way of collaborating with one another in other to provide adequate information for their users, since there is no institution that is self-sufficient and they all have a common goal; and their research are inter related in one way or the other. 
4. Since it has been noted that for up-to-date information, agricultural researchers in Nigeria prefer attending conferences and seminars for information, research libraries should find a way of collating information from conferences and seminars together for references in the institutions. This can be done by sponsoring the information personnel i.e. Librarian in the institutions to their conferences as well for information gathering.

5. Librarians and other information staff should wake up to their responsibilities in helping agricultural researchers to source for information. This can be done through selected information dissemination (SDI), thereby making themselves relevant in their profession and justify purpose of their existence in the institutions. This will also give room for authorities involved to have positive defence for library budget.

\section{References}

1. Andrzej, C. (2007). The proceeding of the Twentieth World Congress of Philosophy. The Paideia Project.

2. Ankpa S.A. (2000). Student's use of University of Maiduguri Library. An evaluation study. Gateway Libr. J., 28(3), 73-80.

3. Annan, K. (2003). Information and communication development. The World Summit on Information and Society (WSIS), Geneva

4. Anwar, M. A. (2007). Research on Information Seeking and Use in Pakistan: An Assessment. Pakistan Journal of Library and Information Science, 1 (8), 15-32.

5. Bates, M. J. (2010). Information Behaviour in Encyclopaedia of Library and Information Sciences, 3rd Ed .New York: CRC Press, 3, 2381-2391.

6. Case, D.O. (2007). Looking for Information: A survey of research on Information, needs and behaviour. Boston: MA Elsevier/Academic Press.
7. Ezeala, L.O \& Yussuf, E.O. (2011). Users Satisfaction with Library Resources and Services

8. In Nigeria Agricultural Research Institutes. Library Philosophy \& Practice, 2, 9-12.

9. Kakai, M., Ikoja-Odongo, R. andBukenya, K. (2004). A study of the Information Seeking Behaviour of Undergraduate Students of Makerere University, Uganda. World Libraries. 14 (1).

10. Kuhlthau, C.C. (2005). Kuhltau's Information Search Process, in Theories of information behaviour, edited by KE. Fisher, S Erdelez and L McKechnie.Medford: Published for the American Society for Information Science and Technology by Information Today: 230-234.

11. Mabawonku, I. (2005). The Information Needs of Artisans: A Case Study of Artisans in Ibadan, Nigeria. Lagos Journal of Library and Information Science. 3(1), 61-76.

12. Majid, S., \& Kassim, G.M. (2000). Information seeking behaviour of International Islamic

a. university Malaysia law faculty members. Malaysian Journal of Library and Information Science 5(2): 1-17.

13. Robinson, M.A. (2010). An Empirical Analysis of Engineers Information Behaviour. Journal of American Society of Information Science and Technology. 61(4).

14. Rouse, M. (2000): What is Information (Information as a Stimuli). International Bulletin of Missionary Research, 1(6).

15. Shaib, B., Adedipe, N.O. and Aliyu, O. A. (2003). Towards strengthening the Nigerian Agricultural Research System, NARP Pub. $39-43$

16. Singh, K.P. and Satija, M.P. (2007) .Information Seeking Behaviour of Agriculture Scientists with Particular Reference to their Information Seeking Strategies. Annals of Library and Information student, 54, 213-220.

17. Spicker, P. (2007). Research withoutConsent.Social Research Update 51 winter, 1-4

18. Wilson, T. D. (1999). Models in Information Behaviour Research. Journal of Documentation. 55(3), 249-270. [Available http://informationr.net/tdw/publ/papers/1999JDoc.html]

19. Yousefi, A. and Yousefi, S. (2007). Information Need and Information Seeking behaviour of Professionals at an Iranian Company. Library Student Journal. 65,124-129. 